\title{
Inactivation of Vaccinia Virus by Ascorbic Acid
}

\author{
BY G. S. TURNER \\ Virus Vaccine Department, Lister Institute of Preventive Medicine, \\ Elstree, Hertfordshire
}

(Received 1 October 1963)

\begin{abstract}
SUMMARY
Ascorbic acid undergoing auto-oxidation inactivated vaccinia virus. Copper ion was shown to have a catalytic effect on the inactivation. Neither unoxidized ascorbic acid nor its oxidation product, dehydroascorbic acid, were inhibitory. When ascorbic acid was oxidized at high $\mathrm{pH}$ in the absence of copper ion no inactivation took place. Similarly, enzymic oxidation of ascorbic acid in the absence of copper was without effect on the virus. Catalase prevented inactivation but not the oxidation of ascorbic acid. Glutathione prevented both inactivation and the oxidation of ascorbic acid. Inhibition experiments with ascorbic acid under anaerobic conditions were inconclusive. The mechanism of ascorbic acid inactivation is discussed in the light of these data and that of other authors with different viruses.
\end{abstract}

\section{INTRODUCTION}

During experiments on the stability of vaccinia virus in the presence of various reducing agents, it was found that ascorbic acid was strongly inhibitory. Kligler \& Bernkopf (1937) noted this phenomenon, and Jungeblut (1935) reported that ascorbic acid inactivated poliovirus. Similar results have been reported for herpes virus (Holden \& Resnick, 1936; Holden \& Molloy, 1937), bacteriophages (Lominski, 1936) and tobacco mosaic virus (Lojkin, 1936). Lojkin made a systematic study of the inhibitory effects of ascorbic acid on tobacco mosaic virus infectivity; our results with vaccinia virus are in many respects like hers.

\section{METHODS}

Virus. The Lister Institute vaccine strain of vaccinia virus was used throughout the experiments. It was prepared from sheep dermal pulp in 0.004 M-McIlvaine

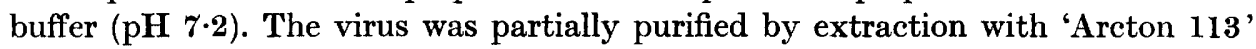
(trifluorotrichloroethane, I.C.I.) followed by one cycle of high-speed centrifugation. It was stored in small volumes at $-70^{\circ}$. Such preparations produced cytopathic changes in monkey kidney tissue cultures in dilutions of $10^{-6}$ to $10^{-8}$.

Virus titrations. Suitable dilutions of samples were inoculated in $0 \cdot 1 \mathrm{ml}$. volumes into roller tube cultures of 2nd cycle monkey kidney cells; four tubes were used per dilution. Cytopathic changes were evident in $48 \mathrm{hr}$ with high concentrations of virus, but the tubes were examined daily until the seventh day after inoculation, when no further changes were recorded. Fifty \% end-points (TCD 50) were calculated by the method of Reed \& Muench (1938).

Buffers were prepared from McIlvaine's $0 \cdot 2$ M-disodium phosphate $+\mathbf{0} \cdot \mathbf{1}$ M-citric 
acid solutions, which were mixed and diluted to give the desired $\mathrm{pH}$ value and molarity. Unless otherwise stated, all experiments were done in buffer at $\mathrm{pH} 6 \cdot 9$.

Enzymes. Catalase was a commercial beef-liver preparation (Light and Co.). It was used in different experiments in final concentrations of 10 and $4.0 \mathrm{mg} . / \mathrm{ml}$.

Ascorbic acid oxidase (ascorbate oxidase) was prepared from fresh cabbage by freezing whole cabbage-heart at $-70^{\circ}$ and then expressing the juice in a press. The juice was dialysed overnight against distilled water, and an equal volume of cold acetone was added to the dialysis residue. The resulting precipitate was dissolved in distilled water of one-tenth of the original volume of juice. This preparation was stored at $-70^{\circ}$; at $\mathrm{pH} 6.8$ and $37^{\circ}, 0.2 \mathrm{ml}$. of this solution in a total volume of $2.0 \mathrm{ml}$. completely oxidized $180 \mu \mathrm{g}$. ascorbic acid in $2 \mathrm{hr}$.

Copper solution was $0 \cdot 1 \mathrm{M}^{-\mathrm{CuSO}_{4}}$ in distilled water. It was added to ascorbic acid + virus mixtures to a final copper concentration of $5 \mu \mathrm{g} . / \mathrm{ml}$.

Ascorbic acid (British Drug Houses Ltd.) was prepared in solutions of various strengths in $\mathrm{pH} 6.8$ buffer immediately before use. The concentration of ascorbic acid was estimated by titration against standard B.D.H. dichlorophenolindophenol.

Cystein hydrochloride, glutathione and thioglycollic (mercaptoacetic) acid were dissolved in distilled water and diluted in buffer of the desired $\mathrm{pH}$ value.

\section{RESULTS}

In preliminary experiments samples of virus containing $5 \times 10^{3} \mathrm{TCD} 50 / \mathrm{ml}$. were exposed to cysteine, glutathione, thioglycollic acid or ascorbic acid at $100 \mu \mathrm{g} . / \mathrm{ml}$. for $18 \mathrm{hr}$ at $37^{\circ}$ and $\mathrm{pH} 7 \cdot 4$. Whereas the three thiol-containing reducing substances were without effect, ascorbic acid decreased the virus titre to $<10 \mathrm{TCD} 50 / \mathrm{ml}$. This inactivation was not abolished by dialysis of the virus + ascorbic acid mixture against water. Tissue culture cells, pretreated for 2 days at $37^{\circ}$ with ascorbic acid $200 \mu \mathrm{g} / \mathrm{ml}$. had no altered susceptibility to virus. The inactivating effect of ascorbic acid on vaccinia virus was also shown by titration of samples on the chorioallantoic membranes of chick embryos.

Effect of copper. The autoxidation of ascorbic acid is a well-known phenomenon and is catalysed by copper ions (Barron, Demilio \& Klemperer, 1936). Preliminary experiments showed that $\mathrm{Cu}^{2+} \mathbf{5} \mu \mathrm{g}$. $/ \mathrm{ml}$. was itself without effect on the virus, but it increased both the rate and degree of inactivation by ascorbic acid in ascorbic acid + vaccinia virus mixtures. The $\mathrm{Cu}^{2+}$ also increased the rate of oxidation of ascorbic acid in the mixture (Fig. 1).

Effect of concentration of ascorbic acid. Vaccinia virus has an optimum stability at $\mathrm{pH} \mathrm{6 \cdot 8-7 \cdot 0}$ at $37^{\circ}$; accordingly, quantitative experiments with ascorbic acid were performed in undiluted McIlvaine buffer at $\mathrm{pH} 6 \cdot 9$. Vaccinia virus with an initial titre of $10^{8.5} \mathrm{TCD} 50 / \mathrm{ml}$. was diluted $1 / 100$ and mixed with different quantities of ascorbic acid. The mixtures were incubated at $37^{\circ}$ and samples examined at various times for infectious virus. A control sample of virus alone was titrated after incubation for the maximum time. All the mixtures contained $5 \mu \mathrm{g} . \mathrm{Cu}^{2+} / \mathrm{ml}$. The concentration of ascorbic acid and the time of exposure influenced the inactivation of vaccinia virus; quantities as small as $50 \mu \mathrm{g}$. ascorbic acid $/ \mathrm{ml}$. fully inactivated $10^{6.5}$ TCD 50 in $2 \mathrm{hr}$ at $37^{\circ}$ and amounts as little as $10 \mu \mathrm{g}$. caused partial inactivation after $24 \mathrm{hr}$ (Table 1). 


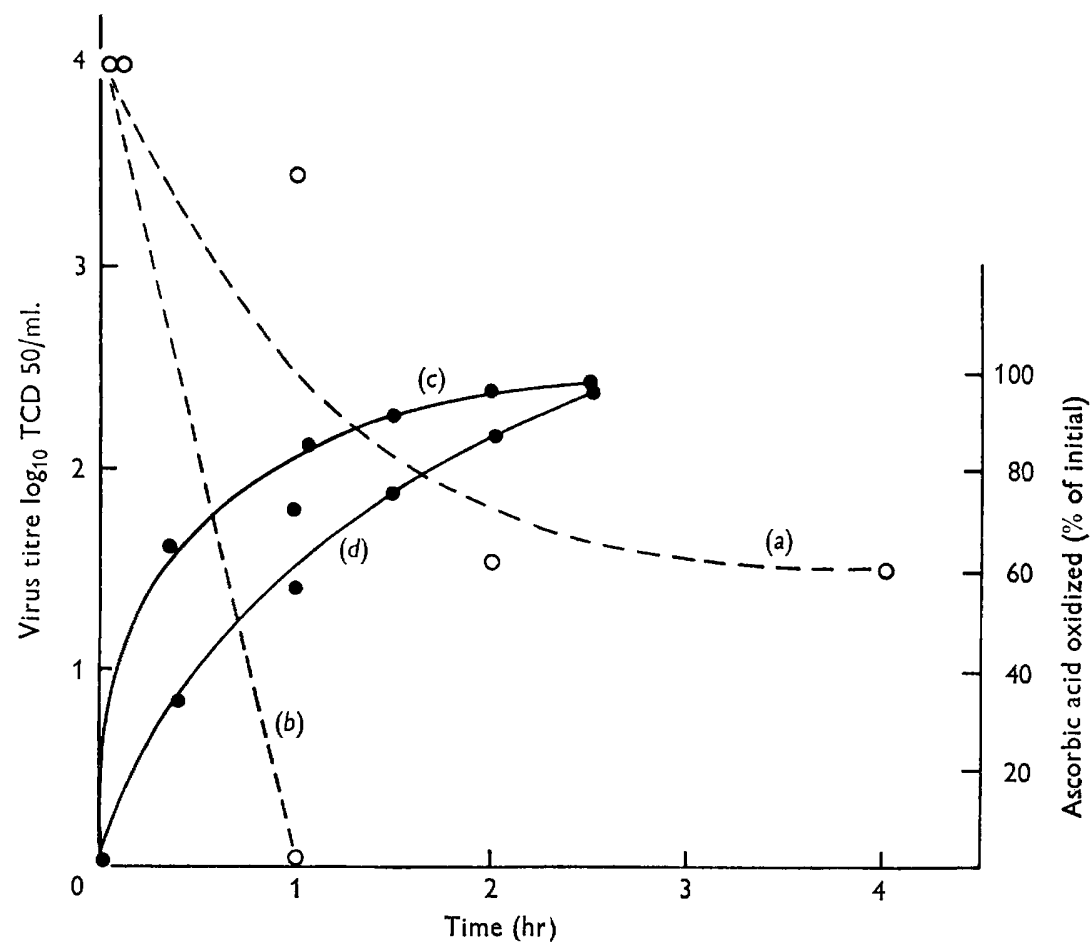

Fig. 1. Vaccinia virus 10,000 TCD 50 that was exposed to ascorbic acid $100 \mu \mathrm{g} . / \mathrm{ml}$. at $37^{\circ}$ and $\mathrm{pH}$ 7.4. Curve $(a)$ open circles virus titre without $\mathrm{Cu}^{2+}$. Curve $(b)$ open circles virus titre $+\mathrm{Cu}^{2+} \mathbf{5} \mu \mathrm{g} . / \mathrm{ml}$. Curve $(c)$ closed circles \% ascorbic acid oxidized in the presence of $\mathrm{Cu}^{2+} 5 \mu \mathrm{g}$. $/ \mathrm{ml}$. Curve $(d)$ closed circles \% ascorbic acid oxidized in the absence of $\mathrm{Cu}^{2+}$.

Effect of dehydroascorbic acid. An inhibitory concentration of ascorbic acid (100 $\mu \mathrm{g} . / \mathrm{ml}$.) was oxidized with an equivalent quantity of potassium permanganate. Although potassium permanganate inactivates vaccinia virus, the amount required to oxidize $100 \mu \mathrm{g}$. ascorbic acid was calculated to be less than the inhibitory concentration. Only partial inactivation occurred when the sample of oxidized ascorbic

Table 1. Effect of ascorbic acid on the infectivity of vaccinia virus suspensions

\begin{tabular}{|c|c|c|c|c|c|c|c|}
\hline \multirow{2}{*}{$\begin{array}{l}\text { Ascorbic acid } \\
\text { (mg./ml.) }\end{array}$} & \multicolumn{6}{|c|}{ Time of exposure (hr) } & \multirow{2}{*}{$\begin{array}{c}\text { Amount of } \\
\text { ascorbic acid } \\
\text { oxidized at time } \\
\text { of inacti- } \\
\text { vation of virus } \\
\text { ( } \mu \mathrm{gg} \text {.) }\end{array}$} \\
\hline & $\mathbf{0}$ & $\mathbf{0 . 2 5}$ & 0.5 & $1 \cdot 0$ & $\mathbf{2} \cdot \mathbf{0}$ & $24 \cdot 0$ & \\
\hline \multicolumn{8}{|c|}{ Relative degree of virus inactivation } \\
\hline $1 \cdot 0$ & - & + & + & + & + & + & $80-190$ \\
\hline 0.5 & - & - & \pm & + & + & + & 140 \\
\hline $0 \cdot 25$ & - & - & + & + & + & + & 70 \\
\hline $0 \cdot 125$ & - & - & + & + & + & + & 65 \\
\hline 0.0625 & - & - & - & \pm & + & + & 50 \\
\hline $0 \cdot 05$ & - & - & - & $\overline{-}$ & - & \pm & 50 \\
\hline 0.01 & - & - & - & - & - & $\overline{ \pm}$ & 10 \\
\hline
\end{tabular}

$+=$ complete inactivation; $\pm=$ partial inactivation; $-=>10 \mathrm{TCD} 50$ active virus still present. 
acid was held with virus overnight at $37^{\circ}$. Ascorbic acid (125 $\mu \mathrm{g} . / \mathrm{ml}$.) completely oxidized with ascorbic acid oxidase did not inactivate vaccinia virus after $2 \mathrm{hr}$ at $37^{\circ}$. Controls of unoxidized ascorbic acid in this concentration inactivated completely. The infectivity of untreated virus under these conditions was unaltered.

Effect of ascorbic acid oxidase (ascorbate oxidase). The rapid oxidation of ascorbic acid can be catalysed without added $\mathrm{Cu}^{2+}$ by the enzyme hexoxidase. Virus and ascorbate oxidase preparation in $\mathrm{pH} 6.9$ buffer were mixed to give a virus titre of $10^{6} \mathrm{TCD} 50 / \mathrm{ml}$. and a concentration of enzyme preparation of $20 \%(\mathrm{v} / \mathrm{v})$. To one portion of this mixture ascorbic acid was added to $125 \mu \mathrm{g} . / \mathrm{ml}$. The second portion was adjusted to the same volume by adding $\mathrm{pH} 6.9$ buffer. Controls consisting of virus alone and virus + ascorbic acid $+\mathrm{Cu}^{2+}$ were set up at the same time. All mixtures were incubated at $37^{\circ}$ for $2 \mathrm{hr}$. There was no inactivation of vaccinia virus when the ascorbic acid used had been completely oxidized by ascorbate oxidase in the absence of added $\mathrm{Cu}^{2+}$. The enzyme alone was without effect on the virus, which was completely inactivated in the presence of the same concentration of ascorbic acid when oxidation was catalysed by $\mathrm{Cu}^{2+}$. These results confirmed that the oxidation product of ascorbic acid (dehydroascorbic acid) did not inactivate and indicate that the copper catalysed oxidation of ascorbic acid (probably in the presence of oxygen) was necessary for inactivation, and that the enzyme-catalysed oxidation proceeds by different mechanism. These findings are like those of Lojkin (1936) with tobacco mosaic virus.

Effect of catalase. The addition of catalase to ascorbic acid + tobacco mosaic virus mixtures abolishes the inactivating effect of ascorbic acid (Lojkin, 1936). Similarly, the addition of beef-liver catalase $4 \mathrm{mg}$. $/ \mathrm{ml}$. completely prevented the inactivation of vaccinia virus in a buffered mixture containing $10^{6.5}$ TCD 50 virus $/ \mathrm{ml}$. + ascorbic acid $125 \mu \mathrm{g} . / \mathrm{ml}$. $+\mathrm{Cu}^{2+} 5 \mu \mathrm{g} . / \mathrm{ml}$. held at $37^{\circ}$ for $2 \mathrm{hr}$. Inactivation occurred when the catalase was omitted from a similar mixture or when the enzyme was inactivated by boiling before addition. The enzyme alone was without effect on the virus, and did not prevent the oxidation of ascorbic acid. The ascorbic acid in the mixture was about $90 \%$ oxidized.

Effect of high $p H$ values. Barron et al. (1936) showed that the autoxidation of ascorbic acid was increased in alkaline media in the absence of catalytic $\mathrm{Cu}^{2+}$. Vaccinia virus and ascorbic acid were mixed without added $\mathrm{Cu}^{2+}$ in $\mathrm{pH} 10.0$ buffer to final concentrations of $10^{6} \mathrm{TCD} 50$ and $125 \mu \mathrm{g} . / \mathrm{ml}$. respectively. The mixture, and a virus control at the same $\mathrm{pH}$ value, were incubated for $2 \mathrm{hr}$ at $37^{\circ}$. No inactivation of virus took place, although more than $40 \%$ of the ascorbic acid was oxidized. Exposure to $\mathrm{pH} 10 \cdot 0$ for $2 \mathrm{hr}$ at $37^{\circ}$ had no effect on the virus alone.

Effect of glutathione. The inhibition of vaccinia virus by reduced glutathione reported by Kligler \& Bernkopf (1937) was not confirmed. Not only were glutathione concentrations up to $1.0 \mathrm{mg} . / \mathrm{ml}$. without effect on the virus, but appeared to prevent the oxidation of ascorbic acid in vaccinia virus + ascorbic acid mixtures and consequently the inactivation of virus. Ascorbic acid was added to mixtures of virus and freshly prepared reduced glutathione. The final mixture, containing virus $10^{6 \cdot 5}$ TCD 50/ml., glutathione $125 \mu \mathrm{g} . / \mathrm{ml}$., ascorbic acid $125 \mu \mathrm{g} . / \mathrm{ml}$., and $\mathrm{Cu}^{2+} 5 \mu \mathrm{g} . / \mathrm{ml}$. was held for $2 \mathrm{hr}$ at $37^{\circ}$; suitable controls were included. Glutathione decreased the inactivation by ascorbic acid at $125 \mu \mathrm{g} . / \mathrm{ml}$., and abolished it at $1 \mathrm{mg} . / \mathrm{ml}$. Glutathione prevented the autoxidation of ascorbic acid, but did not reactivate virus when 
added to virus + ascorbic acid mixtures in which inactivation of the virus had already occurred. The substitution of cysteine in the same concentration for glutathione had no effect on the inactivation by ascorbic acid. These experiments also indicate that ascorbic acid itself is not inhibitory when its autoxidation is prevented.

Effect of an atmosphere of nitrogen and anaerobiosis on ascorbic acid inactivation. Several attempts were made to prevent the autoxidation of ascorbic acid in vaccinia virus + ascorbic acid mixtures by gassing the system with oxygen-free nitrogen. In a typical experiment the buffer to be used as diluent was boiled to drive off dissolved air. Oxygen-free nitrogen (British Oxygen Company Limited) was bubbled through a mixture containing $10^{6} \mathrm{TCD} 50 / \mathrm{ml}$. virus and $5 \mu \mathrm{g}$. $\mathrm{Cu}^{2+} / \mathrm{ml}$. for $30 \mathrm{~min}$. before a freshly prepared solution of ascorbic acid was added to $125 \mu \mathrm{g} . / \mathrm{ml}$., the nitrogen bubbling was continued during the $2 \mathrm{hr}$ incubation at $37^{\circ}$. The virus was completely inactivated, although only $15-20 \%$ of the ascorbic acid was oxidized. A Thunberg tube was prepared containing similar concentrations of virus and $\mathrm{Cu}^{2+}$. Ascorbic acid solution was placed in the side arm and the tap opened. This, together with a virus control, was placed in an anaerobic jar. After the usual procedure for producing anaerobic conditions within the jar, the ascorbic acid was tipped into the virus. Again, after incubation at $37^{\circ}$ the virus was inactivated, although only about $11 \%$ of the ascorbic acid was oxidized. The control virus retained its original infectivity. It appears that under these conditions even a small degree of autoxidation of ascorbic acid was sufficient to inactivate the vaccinia virus.

\section{DISCUSSION}

The observations reported here for the inactivation of vaccinia virus by ascorbic acid are similar to those of Lojkin with tobacco mosaic virus. The inactivation of other animal viruses by ascorbic acid has been investigated from different viewpoints. In at least one case the inactivation can be ascribed to a direct $\mathrm{pH}$ effect; in other cases no cognizance was taken of the ready autoxidation of ascorbic acid, the catalysis of this oxidation by minute amounts of cupric ion, or the effect of $\mathrm{pH}$ on the autoxidation process. Milas (1932), in a review of autoxidation, stated that autoxidations induce the oxidation of other substances that are relatively unaffected by free oxygen. The inactivation of tobacco mosaic virus by ascorbic acid has been explained not as a reduction, but an oxidation effected by an intermediate unstable peroxide formed during the autoxidation of ascorbic acid catalysed by $\mathrm{Cu}^{+}$. Although the identity of the peroxide was not established, the addition of catalase to ascorbic acid + tobacco mosaic virus mixtures abolished the inactivation (Lojkin, 1936). Catalase likewise prevented the inhibition of vaccinia virus by ascorbic acid, presumably by destroying peroxides, although it did not prevent the autoxidation of ascorbic acid. Peloux, Lofre, Cier \& Colobert (1962) inactivated poliovirus with hydrogen peroxide and ascorbic acid and suggested that free hydroxyl radicals induced by iron and copper ions were responsible. Berneis (1963) showed that ascorbic acid degraded deoxyribonucleic acid, a degradation that could be abolished by catalase or peroxidase; he too concluded that free hydroxyl radicals rather than intermediate peroxides were involved. Free radicals drastically alter the properties of both synthetic and natural polymers. The inactivation of vaccinia virus might similarly be explained on this basis. Whether viral protein or nucleic acid is attacked remains to be established. 


\section{REFERENCES}

Barron, E. S. G., Demilio, R. H. \& Klemperer, F. (1936). Studies on biological oxidations. V. Copper and haemochromogens as catalysts for the oxidation of ascorbic acid. The mechanism of the oxidation. J. biol. Chem. 113, 625 .

Berneis, K. (1963). Der Abbau von Desoxyribo-nucleinsäure durch Ascorbinsäure: Die intermediäre Bildung von OH-Radikalen. Helv. chim. Acta, 46, 57.

Holden, M. \& RESNICK, R. (1936). The in vitro action of synthetic crystalline vitamin C (ascorbic acid) on Herpes virus. J. Immunol. 31, 455.

Holden, M. \& Molloy, E. (1937). Further experiments on the inactivation of Herpes virus by vitamin $\mathrm{C}$ (ascorbic acid). J. Immunol. 33, 251.

Jungeblut, C. W. (1935). Inactivation of poliomyelitis virus in vitro by crystalline vitamin C (ascorbic acid). J. exp. Med. 62, 517.

KLIGLER, I. J. \& BERNKopF, H. (1937). Inactivation of vaccinia virus by ascorbic acid and glutathione. Nature, Lond. 139, 965.

LoJkIN, M. (1936). A study of ascorbic acid as an inactivating agent of tobacco mosaic virus. Contr. Boyce Thompson Inst. Pl. Res. 8, 455.

Lominski, I. (1936). Inactivation du bacteriophage par l'acide ascorbique. C. r. Séanc. Soc. Biol. 122, 766.

Mrlas, N. A. (1932). Auto-oxidation. Chem. Rev. 10, 295.

Peloux, Y., Lofre, C., Cier, A. \& Colobert, A. (1962). Inactivation du virus poliomyélitique par des systèmes chimique générateurs du radical libre hydroxyle. Méchanism de l'activité virulicide du peroxyde d'hydrogène et de l'acide ascorbique. Annls Inst. Pasteur, Paris, 102, 6.

Reed, L. J. \& Muench, H. (1938). A simple method for estimating fifty per cent end points. Am. J. Hyg. 27, 493. 